INTERNATIONAL FOOD

POLICY RESEARCH INSTITUTE

sustainable solutions for ending hunger and poverty

Supported by the CGIAR

IFPRI Discussion Paper 00943

December 2009

\title{
Formal-Informal Economy Linkages and Unemployment in South Africa
}

\author{
Rob Davies \\ James Thurlow
}

Development Strategy and Governance Division 


\section{INTERNATIONAL FOOD POLICY RESEARCH INSTITUTE}

The International Food Policy Research Institute (IFPRI) was established in 1975. IFPRI is one of 15 agricultural research centers that receive principal funding from governments, private foundations, and international and regional organizations, most of which are members of the Consultative Group on International Agricultural Research (CGIAR).

\section{FINANCIAL CONTRIBUTORS AND PARTNERS}

IFPRI's research, capacity strengthening, and communications work is made possible by its financial contributors and partners. IFPRI receives its principal funding from governments, private foundations, and international and regional organizations, most of which are members of the Consultative Group on International Agricultural Research (CGIAR). IFPRI gratefully acknowledges the generous unrestricted funding from Australia, Canada, China, Finland, France, Germany, India, Ireland, Italy, Japan, Netherlands, Norway, South Africa, Sweden, Switzerland, United Kingdom, United States, and World Bank.

\section{AUTHORS}

\section{Rob Davies, Human Sciences Research Council} Visiting Fellow

James Thurlow, International Food Policy Research Institute

Research Fellow, Development Strategy and Governance Division Email: j.thurlow@cgiar.org

Copyright 2009 International Food Policy Research Institute. All rights reserved. Sections of this document may be reproduced for noncommercial and not-for-profit purposes without the express written permission of, but with acknowledgment to, the International Food Policy Research Institute. For permission to republish, contact ifpri-copyright@cgiar.org. 


\section{Contents}

Acknowledgements $\quad \mathrm{V}$

Abstract vi vi

1. Introduction 1

2. A Typology of Informal Activities and Employment 2

3. Measuring and Modeling Formal-Informal Linkages 5

4. Three Policy Simulations 11

5. Conclusion 17

Appendix: Mathematical Specification of the Model 18

References $\quad 21$ 


\section{List of Tables}

1. Four types of informal employment 3

2. Employment profile, $2004 \quad 4$

3. Informal market expenditure shares, $2000 \quad 6$

4. Economic structure of South Africa's informal economy, $2002 \quad 9$

5. Household population patterns, $2000 \quad 10$

6. Initial tariff rates and collections, 2002

7. Changes in production under alternative policy simulations 12

8. Changes in employment under alternative policy simulations 13

9. Changes in incomes under alternative policy simulations 14

$\begin{array}{ll}\text { A.1. Model equations } & 18\end{array}$

A.2. Model sets, parameters, and variables $\quad 20$

\section{List of Figures}

1. Conceptual framework for the formal-informal economywide model 


\section{ACKNOWLEDGEMENTS}

We thank Miriam Altman (Human Sciences Research Council) and Imraan Valodia (University of KwaZulu-Natal) for their invaluable comments and suggestions, and for their management of the broader research program on South Africa's informal sector. Funding from the Human Sciences Research Council is gratefully acknowledged. 


\begin{abstract}
South Africa's high involuntary unemployment and small informal sector are attributed to an underperforming formal sector and barriers to entry in the informal sector. This paper examines the economywide linkages between the formal and informal economies while accounting for different types of informal activities. A multiregion empirically calibrated general equilibrium model is developed capturing both product and labor markets. Three policy options are considered. First, results indicate that trade liberalization reduces national employment. At the same time, it increases formal employment, hurts informal producers, and favors informal traders, who benefit from lower import prices. Past liberalization may, therefore, partly explain South Africa's small informal sector and its concentration among traders rather than producers. Second, wage subsidies on low-skilled formal workers increase national employment but hurt informal producers by heightening competition in domestic product markets. This suggests that it is insufficient to examine unemployment policies by focusing only on labor markets. Third, unconditional cash transfers stimulate demand for informally produced products, thereby raising informal employment without undermining formal producers. The transfer does, however, place a large fiscal burden on the state and is less effective at reducing national unemployment than a wage subsidy. Overall, these findings underline the importance of distinguishing between the formal and informal sector implications of socioeconomic policies.
\end{abstract}

\title{
Keywords: informal economy, CGE model, South Africa
}




\section{INTRODUCTION}

Unemployment is one of South Africa's most pressing socioeconomic challenges, affecting a quarter of the workforce. Rodrik (2008) identifies manufacturing's poor performance relative to skill-intensive services as the main cause behind rising unemployment among lower-skilled job seekers. Moreover, most of manufacturing's decline since the end of apartheid is attributed to low profitability caused by rising import competition. As a result, formal sector job creation has failed to keep pace with expanding labor force participation. It is expected then that the unemployed would turn to the informal sector, and, indeed, informal employment has accounted for most of the job creation over the last decade (Casale, Muller, and Posel 2004). However, despite that expansion, South Africa has a small informal sector compared with other countries at similar income levels (Maloney 2004; Schneider 2002). Supporting this observation, Kingdon and Knight (2004) show that unemployment in South Africa is involuntary and that informal work is preferred. This suggests that significant barriers to entry exist in the informal sector, such as poor access to credit, high levels of crime, and a reservation wage inflated by social transfers (Ranchhod 2006).

High unemployment in South Africa is thus attributed to an underperforming formal sector and to the inability of the unemployed to enter informal labor markets. However, few studies have examined the linkages between South Africa's formal and informal sectors. In other words, how has the structure and size of the formal sector influenced employment incentives and opportunities in the informal sector? Moreover, studies that do consider formal-informal sector linkages typically focus on tax policies, such as expanding the tax base, or on labor market interactions, such as trade unions' protection of formal employment (see, for example, Schultz and Mwabu 1998; Lucas and Hofmeyr 2001). Such studies do not address formal-informal sector competition in product markets, which may also influence the size and composition of the informal sector, and hence indirectly the high level of unemployment.

In this paper we examine how South Africa's formal sector affects informal production and employment. Given the diversity of the informal sector, Section 2 uses recent household and labor force surveys to develop a typology of informal activities based on their different interactions with the formal sector. Drawing on that typology, Section 3 constructs an empirically calibrated economywide model that captures formal-informal sector linkages in both product and labor markets. The model is used in Section 4 to examine three policies that feature prominently in South Africa's current unemployment debate: trade liberalization, formal sector wage subsidies, and unconditional cash transfers. Model results indicate that policies can produce diverging outcomes for formal and informal economies. More specifically, policies favoring formal sector job creation may in fact lower informal employment, while also having differential impacts on different kinds of informal activities. This suggests that formal-informal linkages can explain some of the small size of South Africa's informal sector, as well as its concentration among traders rather than producers. These results also caution against adopting formal sector policies without considering informal sector impacts. The final section discusses these findings and their implications for future research. 


\section{A TYPOLOGY OF INFORMAL ACTIVITIES AND EMPLOYMENT}

\section{Contrasting Views of the Informal Economy}

In contrast to typical dual-economy models, the informal economy is quite diverse and has complex interactions with the formal sector. To begin with, scholars disagree about the role of informal activities in stimulating broader economic development (Devey, Skinner, and Valodia 2003). Some view the informal sector as a dynamic sector with the ability to create jobs and actively contribute to economywide growth. They regard informal activities as small enterprises that may eventually generate tax revenues through a gradual process of formalization. In contrast, others view informal activities as low-productivity employment or as survivalist strategies for poor households. From that perspective, the informal sector plays a passive role in development and acts as a temporary substitute for social protection during the formal-sector-led growth process. Evidence from recent surveys in South Africa reveals the heterogeneity of informal activities and suggests that there is room for both perspectives (Berry et al. 2002). Indeed, the informal economy comprises a continuum of survivalist and enterprise activities. This more nuanced view of the role of informal activities highlights the complexity of designing policies that account for differential impacts on formal and informal economies.

There are also differences in the definition of the informal sector (Devey, Skinner, and Valodia 2003). Here we draw a distinction between informal activities and informal employment. Some view informal workers as those who own or are employed by informal or unregistered firms. Indeed, this is the view held by official statistics in South Africa. In contrast, others take a broader view and include workers informally employed within the formal sector (Hussmanns 2001). For example, the former (narrower) definition includes informal producers and traders, whereas the latter (broader) definition includes day laborers and seasonal farmworkers working for formal firms or farms but without contracts or benefits. The distinction is important. For example, under the narrower definition, South Africa has a disproportionately small informal sector (i.e., 2.35 million informal workers, or one-fifth of total employment). Under the broader definition, an additional 1.45 million workers are classified as informally employed (excluding domestic workers and subsistence agriculturalists). 1 This raises the share of broadly defined informal employment to more than one-third of total employment. Although this redefined informal sector measurement is not directly comparable across countries, it is more consistent with other countries at similar income levels (Maloney 2004; Schneider 2002). Thus, a broader view of informal employment is preferred to conventional distinctions between formal and informal sectors. It also highlights the complex linkages between formal and informal economies.

\section{A Typology of Formal-Informal Activities}

We develop a typology based on the nature of informal activities' interactions with the formal sector. Table 1 lists the four types of informal activities that we identify: (i) informal producers who compete with formal producers in product markets; (ii) informal traders who sell formal sector products and charge a fixed transaction cost margin; (iii) workers who are informally employed in producing formal sector products; and (iv) informally employed workers producing goods and services that are not produced by the formal sector (i.e., noncompetitive producers).

The first category, informal producers, includes small enterprises producing goods and services that compete with formal sector firms producing similar products. Examples include processed foods, textiles, and clothing. Informal producers generate employment for other informal workers, and they compete in product markets based on the price at which they can supply their goods. Thus the main linkages between informal producers and the formal sector are through the purchasing of formal sector intermediates and through the selling of commodities under price competition to formal consumers. This employment type closely corresponds to the official definition of the informal sector (i.e., workers in

1 Calculations based on the 2004 Labor Force Survey (September) (StatsSA, 2004). 
unregistered or untaxed businesses). According to the September 2004 Labor Force Survey (LFS2004) (StatsSA, 2004) about 1.55 million workers fell into this category out of a total employed workforce of 10.6 million (see column 4 in Table 2). Note that this is total informal sector employment less informal traders, who form the second category in the typology.

Table 1. Four types of informal employment

\begin{tabular}{llll}
\hline & $\begin{array}{l}\text { Are distinct formal } \\
\text { and informal goods } \\
\text { produced? }\end{array}$ & $\begin{array}{l}\text { Is there price } \\
\text { competition between } \\
\text { formal and informal } \\
\text { goods? }\end{array}$ & $\begin{array}{l}\text { Is there wage } \\
\text { competition between } \\
\text { formal and informal } \\
\text { workers? }\end{array}$ \\
\hline $\begin{array}{l}\text { Informal producers } \\
\text { (e.g., food, clothing, transport) }\end{array}$ & Yes & Yes & No \\
$\begin{array}{l}\text { Informal traders } \\
\text { (e.g., street vendors) }\end{array}$ & No & $\begin{array}{l}\text { No } \\
\text { (fixed margin) }\end{array}$ & No \\
$\begin{array}{l}\text { Informally employed in formal sector } \\
\text { (e.g., construction day laborers) }\end{array}$ & No & No & Yes \\
$\begin{array}{c}\text { Noncompetitive informal activities } \\
\text { (e.g., domestic workers) }\end{array}$ & No & $\begin{array}{l}\text { No } \\
\text { (sold to formal sector) }\end{array}$ & No \\
\hline
\end{tabular}

Informal traders differ from informal producers in that they do not produce a product but rather provide a service to consumers. Accordingly, they do not compete directly with formal producers over price. Rather, as a generalization, they purchase formal sector goods, which they sell on to consumers with a fixed markup or margin. This means that informally traded goods will often have a higher price than those that are formally traded. This higher price is possible because informal traders often trade formally purchased goods in smaller volumes than formal retailers (i.e., "regrating" or price discrimination) or they trade in closer proximity to final consumers (e.g., at taxi ranks or along the road). According to LFS2004, about 805,000 workers are engaged in informal trade, thus forming a large part of South Africa's overall informal sector (see column 4 in Table 2). 
Table 2. Employment profile, 2004

\begin{tabular}{clllllll}
\hline & $\begin{array}{l}\text { All } \\
\text { workers }\end{array}$ & $\begin{array}{l}\text { Formal } \\
\text { sector } \\
\text { workers }\end{array}$ & $\begin{array}{l}\text { Informally } \\
\text { employed } \\
\text { workers }\end{array}$ & $\begin{array}{l}\text { Informal } \\
\text { sector } \\
\text { workers }\end{array}$ & $\begin{array}{l}\text { Skilled } \\
\text { workers }\end{array}$ & $\begin{array}{l}\text { Semiskilled } \\
\text { workers }\end{array}$ & $\begin{array}{l}\text { Unskilled } \\
\text { workers }\end{array}$ \\
\hline Total employment (1,000s) & 10,556 & 6,754 & 1,451 & 2,351 & 2,048 & 4,826 & 3,682 \\
Employment share (\%) & 100.0 & 100.0 & 100.0 & 100.0 & 100.0 & 100.0 & 100.0 \\
$\quad$ Agriculture & 10.3 & 6.9 & 9.8 & 20.3 & 2.0 & 3.9 & 23.3 \\
Manufacturing & 14.7 & 18.9 & 5.4 & 8.3 & 11.2 & 21.2 & 8.1 \\
$\quad$ Food and beverages & 2.5 & 3.4 & 1.1 & 0.7 & 1.5 & 3.3 & 2.0 \\
\hline Textiles and clothing & 2.9 & 3.0 & 1.2 & 3.6 & 0.6 & 5.3 & 1.0 \\
$\quad$ Other manufactures & 9.3 & 12.4 & 3.1 & 4.0 & 9.1 & 12.6 & 5.0 \\
Construction & 7.3 & 4.7 & 8.9 & 13.6 & 2.5 & 11.0 & 5.1 \\
Mining and utilities & 4.4 & 6.9 & 0.0 & 0.0 & 2.5 & 7.4 & 1.6 \\
Services & 63.3 & 62.6 & 75.9 & 57.7 & 81.8 & 56.5 & 62.0 \\
$\quad$ Retail trade & 17.7 & 14.1 & 7.3 & 34.3 & 10.3 & 20.4 & 18.2 \\
$\quad$ Restaurants & 3.3 & 3.6 & 2.5 & 3.0 & 3.0 & 5.0 & 1.3 \\
$\quad$ Transport & 4.8 & 5.0 & 3.2 & 5.1 & 5.6 & 6.4 & 2.2 \\
\hline Business & 9.1 & 13.3 & 1.0 & 2.0 & 16.1 & 10.5 & 3.4 \\
$\quad$ Government & 10.4 & 16.2 & 0.0 & 0.0 & 29.2 & 7.7 & 3.5 \\
$\quad$ Other services & 18.1 & 10.3 & 61.9 & 13.4 & 17.5 & 6.6 & 33.4 \\
Average wage (rand per worker) & 19,662 & 26,175 & 10,015 & 8,032 & 38,609 & 19,198 & 9,792 \\
\hline
\end{tabular}

Source: Own calculations using the 2004 Labor Force Survey (September) (StatsSA, 2004).

Notes: "Skilled workers" are professionals and managers; "semiskilled" are sales and technicians; and "unskilled" are all others. Some columns do not add to 100 percent due to rounding errors.

Informally employed workers work in the formal sector on a somewhat casual basis (column 3 in Table 2). In other words, they do not have contracts, are not unionized, and receive no benefits. Examples include day laborers in the construction sector or seasonal agricultural workers working on commercial farms. Such workers compete with formal sector workers through their wage rates. In many developing countries, the textiles sector provides a good example to distinguish informal producers from informally employed workers. Informal producers may produce textiles that compete in local markets against formally produced and imported goods. At the same time, other workers may be casually employed in formal textile factories alongside contracted labor, producing goods that are sold in both local and foreign markets. Whereas the first type of formal-informal interaction is through price competition in product markets, the second type of interaction is through wage competition in labor markets.

Finally, we include a fourth type of informal activity: workers who produce goods that are not produced by the formal sector. These types of workers are a subset of workers informally employed in the formal sector. For example, domestic workers might be considered casually employed in the formal sector (despite recent regulations), but they do not face competition from formal sector workers (since no formal sector firms produce domestic services). However, even though there is no competition to produce these services, they are entirely sold in the formal sector and are thus dependent on demand from formal sector consumers (in this case private households receiving most of their incomes from the formal sector). Thus there are still important formal sector linkages for this type of informal activity.

Although any typology is an abstraction for a more complex reality, the preceding classification of informal activities and employment has the advantage of providing a clear framework for understanding how alternative policies may have differential effects on specific actors within the formal and informal economies. Our typology is less concerned with grouping workers based on differences in their specific jobs (for example, taxi drivers versus domestic workers). Rather it identifies the various transmission channels linking formal and informal activities, such as product market prices, labor market wages, and informal trader margins. In the next section we implement this typology within a broader economywide context and develop an integrated multisector model of South Africa's formal and informal economies. 


\section{MEASURING AND MODELING FORMAL-INFORMAL LINKAGES}

In this paper we develop a multiregional computable general equilibrium (CGE) model that captures the observed structure of South Africa's formal and informal economies as well as the various linkages or transmission channels connecting their different economic actors (e.g., firms, traders, government, and investors). A CGE model is a system of equations that describes the functioning or behavior of an entire real economy (i.e., it covers all sectors, institutions, and markets). The parameters of the CGE equations are calibrated to observed data from a social accounting matrix (SAM). A SAM is an economywide database that accounts for all monetary flows in an economy within a specific year. It reconciles a wide range of data sources, including national accounts, household income and expenditure surveys, and labor force surveys. Our analysis therefore required the construction of both a specialized South African Formal-Informal Model (SAFIM) and an accompanying SAM. The mathematical specification of SAFIM is included in the appendix. This section presents a conceptual framework of the model and discusses its structure and core assumptions.

\section{Conceptual Framework of Formal-Informal Sector Linkages}

Figure 1 provides a conceptual framework of the formal-informal sector linkages in SAFIM. The model identifies two regions, representing the formal and informal economies. Each region produces and consumes commodities. The formal region produces a wide range of products and is fairly autonomous, since it produces most of the goods that it consumes and trades directly with the rest of the world. Formal sector firms and households pay taxes to the government, and invest their savings in formal financial institutions. In contrast, the informal region is far from autonomous, since it produces a narrower range of products and does not trade directly with the rest of the world.2 Informal enterprises and households demand products that they do not produce themselves, and so they must purchase ("import") goods from the formal region (i.e., the top interregional arrow in the figure). But this implies that informal region households are spending more money than they earn, which is not sustainable in the long run (i.e., does not describe an equilibrium situation). As shown in the figure, four linkages generate the earnings needed to finance the informal region's trade deficit with the formal region.

2 The informal sector in South Africa does engage in international trade. For example, informal traders may travel to neighboring countries, such as Zimbabwe and Mozambique, to sell their products in those markets. However, such trade is likely to be heavily concentrated along the border and is a very small share of the informal trade with the formal economy and of South Africa's total trade with the rest of the world. For convenience it is excluded from our conceptual framework and empirical analysis. 
Figure 1. Conceptual framework for the formal-informal economywide model

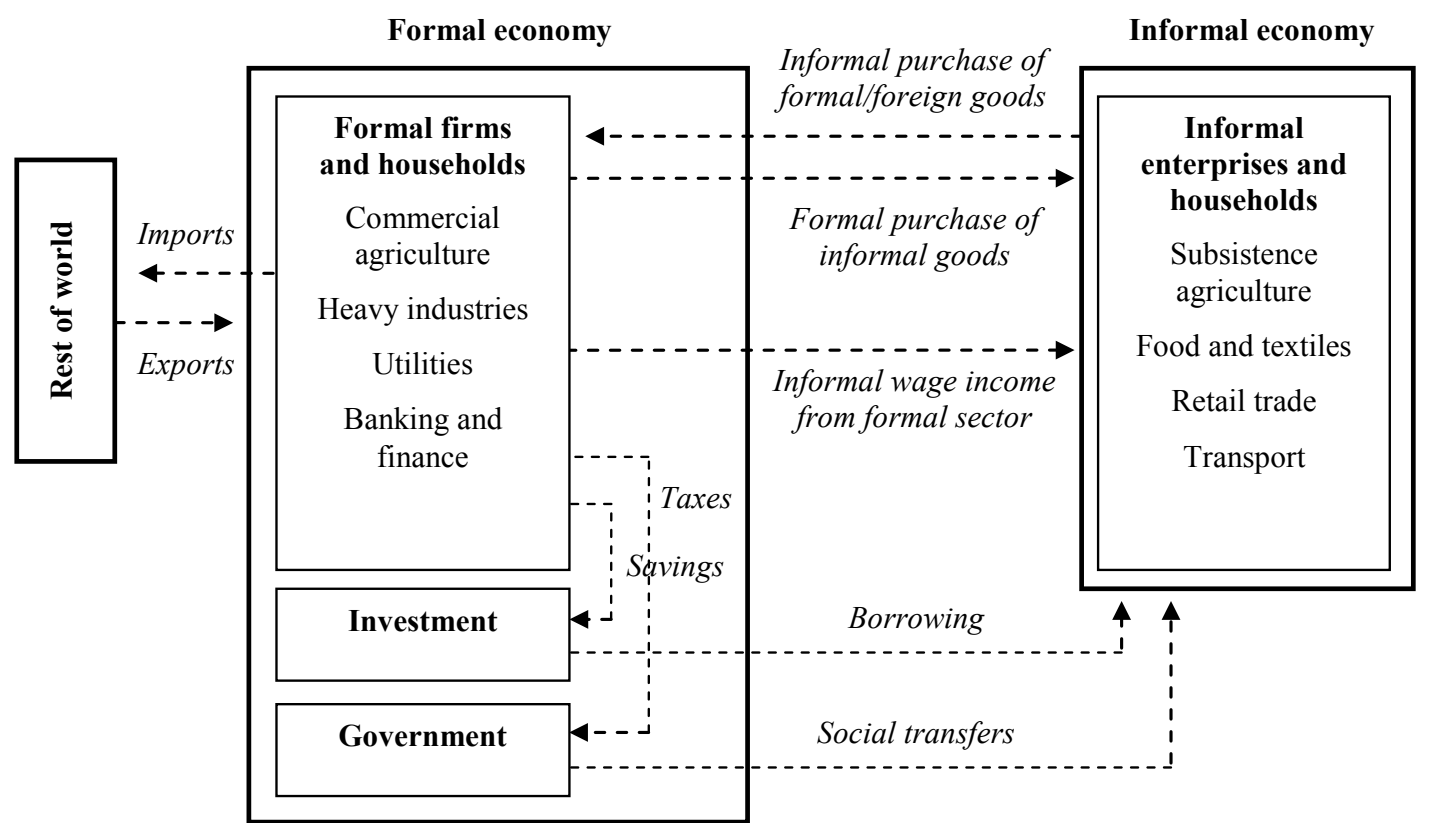

First, the informal region generates external earnings by selling ("exporting") products to the formal region. According to the 2000 Income and Expenditure Survey (IES2000) (StatsSA, 2000) about 5 percent of formal households' food purchases (in value terms) and 3 percent of their nonfood purchases were made in informal markets (see Table 3). 3 In fact, formal and informal households reported similar informal market expenditure shares, thus highlighting the importance of bidirectional formal-informal trade. While lower-income households spend a greater share of their income in informal markets, households in the top expenditure deciles still purchase informally produced and traded products. Overall, the 2002 SAM, which is based on IES2000, estimates that informal sector exports to the formal region cover 77.5 percent of the informal economy's trade deficit with the formal sector (and, indirectly, with the rest of the world). This underlines the importance of product markets for understanding formal-informal linkages.

Table 3. Informal market expenditure shares, 2000

\begin{tabular}{cllll}
\hline & \multicolumn{2}{l}{ Share of purchases (value) in informal markets (\%) } \\
\cline { 2 - 5 } & \multicolumn{2}{l}{ Food products } & \multicolumn{2}{l}{ Nonfood products } \\
\cline { 2 - 5 } & $\begin{array}{l}\text { Formal } \\
\text { households }\end{array}$ & $\begin{array}{l}\text { Informal } \\
\text { households }\end{array}$ & $\begin{array}{l}\text { Formal } \\
\text { households }\end{array}$ & $\begin{array}{l}\text { Informal } \\
\text { households }\end{array}$ \\
\hline All expenditure deciles & 5.1 & 10.1 & 3.2 & 6.6 \\
Deciles 1-5 & 13.4 & 13.5 & 9.8 & 9.7 \\
Deciles 6-8 & 9.2 & 11.3 & 6.8 & 7.1 \\
Deciles 9 & 5.1 & 5.4 & 4.6 & 5.5 \\
Deciles 10 & 1.9 & 3.1 & 1.6 & 4.0 \\
\hline
\end{tabular}

Source: Own calculations using 2000 Income and Expenditure Survey (StatsSA 2000).

Note: "Informal households" include all households reporting earnings from informal employment as well as households with all members who are unemployed.

3 We define "informal households" as those earning any income from the informal sector, including incomes from workers who are informally employed in the formal sector (see Section 2). We also include households that contain only unemployed adult members. All other households are deemed "formal." 
The second source of external earnings for the informal economy is wages earned by workers who are informally employed in the formal sector. Following our two-region conceptual framework, these workers effectively "migrate" to the formal region on a daily basis and remit their wages back to households in the informal region (e.g., domestic workers working for formal households). These remitted incomes can then be used to cover the cost of imports from the formal sector. According to the 2002 SAM, the remitted earnings from informally employed workers covered 15.1 percent of the informal sector's trade deficit.

The remaining two sources of external earnings for the informal sector lie outside of the product and labor markets. To begin with, the informal region is able to borrow externally in order to cover its formal sector purchases. This flow is reversed if informal households as a group are able to save some of their incomes. Second, and more important, informal households are net recipients of social transfers from the government, such as through public pensions or child support grants. Even though informal activities and households are exempt from direct (income and corporate) taxes, the social transfers from the government are still offset by indirect (sales and import) taxes that informal households effectively pay on their formal sector purchases (i.e., on final and intermediate demand). Netting out these indirect tax payments, the 2002 SAM estimates that government inward transfers account for 7.4 percent of the informal sector's trade deficit with the formal sector.

The conceptual framework is a simple representation of the major linkages that need to be captured in any comprehensive model of the formal and informal economies. It therefore provides a foundation for understanding the workings of the more detailed economywide model.

\section{The Formal-Informal Economywide Model}

SAFIM is a multiregional CGE model in which formal and informal economies are represented as regions within the broader South African economy. As seen in Table 2, the formal economy contains most of South Africa's heavier industries (e.g., mining and metals) as well as commercial agriculture and financial services. In contrast, the informal sector covers subsistence agriculture, some lighter manufacturing subsectors, such as food and clothing, and a significant share of trade and transport services. To capture this heterogeneity, SAFIM contains detailed information on demand and supply for 26 economic sectors or commodities in each of the formal and informal regions. Producers in each sector and region employ labor and capital under the assumption of constant returns to scale and profit maximization. For this we use a nested production system, with a constant elasticity of substitution (CES) function determining factor demand, and a Leontief function combining value-added and intermediates.

SAFIM separates skilled, semiskilled, and unskilled workers, which are used with differing intensity in each sector and region. Skilled labor is assumed to be fully employed earning a flexible real wage. In contrast, the supply of semiskilled and unskilled workers is perfectly elastic at a fixed real wage, reflecting the high levels of unemployment observed for these skill groups in South Africa. Based on prevailing wages, all workers from the informal region can seek employment from both informal producers and formal sector firms. This specification of labor markets, together with the separation of formal and informal regions, allows SAFIM to capture the three types of informal employment identified in Section 2: informal producers, workers informally employed in the formal sector, and noncompetitive informal jobs (see Table 1). Finally, capital stocks are immobile across sectors and earn sector-specific returns. The model therefore reflects the complex labor market linkages between the formal and informal sectors.

The second formal-informal economy linkage is trade. The model explicitly allows for both interregional and international trade (i.e., trade between the formal and informal regions, and between South Africa and the rest of the world). Import competition and export opportunities are captured by allowing producers and consumers in the formal and informal regions to shift between "regional" and foreign markets depending on the relative prices of imports, exports, and locally produced goods. More specifically, the decision of formal and informal producers to supply local, regional, or foreign markets is governed by a nonnested constant elasticity of transformation function. Similarly, substitution 
possibilities between local and imported goods are captured by a CES Armington function. This specification permits two-way trade between the formal and informal regions, which, as shown in Table 3 , is an important characteristic of formal-informal interactions. 4 This means that if the informal region is initially a net importer of a particular product, it can still become a net exporter if policies, prices, or productivity improve. Finally, the model also captures the transaction costs that are generated by all goods entering or leaving the informal economy. The transaction costs are paid to the informal retail trade sector. SAFIM therefore captures how changes in trade patterns between the formal and informal sectors generate incomes for informal traders. This is the final kind of informal employment identified in the typology (see Table 1).

Household income and expenditure patterns vary considerably across households living in the formal and informal economies. Such differences are important, since the incomes earned by workers in different sectors benefit households differently according to their initial factor endowments. To capture those differences, the model further separates households in the formal and informal economies into four income subgroups (i.e., expenditure deciles 1-5, 6-8, 9, and 10). These representative households receive factor incomes and social transfers from the formal sector government. This is the third linkage between the formal and informal sectors (see Figure 1). Despite these social transfers, informal households receive most of their income from lower-skilled workers, whereas formal households receive a greater share from capital and higher-skilled workers. All households save some of their income (based on fixed marginal propensities to save), but only formal households pay direct taxes (based on fixed tax rates). Tax rates are highest on higher-income formal households. All households use their remaining income to consume commodities under a Cobb-Douglas demand function.5

Macroeconomic balance is maintained through three "closure" rules. First, for the government account, all tax rates are fixed, and direct and indirect tax revenues are pooled at the national level. These are used to pay for social transfers to households, which are per capita based, and to cover public savings/investment, which are a fixed share of total revenues. The remaining revenues are used for public consumption spending, which generates demand for formal sector products only. Second, for the foreign account, a flexible national exchange rate adjusts to maintain a fixed current account balance measured in foreign currency. Since the domestic price index is the model's numerraire, the exchange is the ratio of the price of tradables to nontradables (i.e., the real exchange rate). Finally, for the savings/investment account, all savings rates are fixed and the supply of loanable funds are pooled at the national level. This is used to finance investment spending, which generates demand for imported and formal sector commodities. Because the model is comparative static, there is no second-period effect on productive capital stocks from changes in investment.

\section{Calibration of the Model}

SAFIM is calibrated to the 2002 South African Formal-Informal Sector SAM. Gross domestic product (GDP) in the 2002 national SAM (see Thurlow 2005) was disaggregated across formal and informal sectors using labor income shares from LFS2004. This assumes that the production technologies of the formal and informal sectors are the same, and that intermediate demand patterns can be allocated in proportion to workers' incomes. All government, investment, and foreign export demand is allocated to formal sector products. Household consumption demand was separated into demand for formal and informal products using detailed informal market consumption shares from IES2000 (see Table 3). Together this provides an estimate of total demand in the formal and informal economies. Finally, we

4 Initial trade flows between the formal and informal economies were estimated using the informal market expenditure shares shown in Table 3, but for a more detailed range of products. Total demand is then compared with production, which was itself estimated using national accounts and labor income data from LFS2004. The CGE model is therefore calibrated to observed formal-informal production structures and consumer behavior.

5 We experimented with the more flexible linear expenditure system of demand, but that produced similar model results. The Cobb-Douglas functional form assumes that the share of disposable income spent on a particular product is independent of a household's income (i.e., unitary income elasticities). The static nature of our model lessens the consequences of that assumption, since household incomes do not change dramatically. 
assume the foreign import penetration is the same across formal and informal sectors. Thus, at this stage, the difference between total demand and supply is the value of regional imports (i.e., a residual approach to estimating trade between two regions). Remaining household incomes and expenditures are based on government accounts and on reported nonfactor incomes in IES2000. The final SAM represents the structural characteristics of the formal and informal economies, including production, trade, and incomes. The initial, or "base," structure of SAFIM is shown in Table 4.

Table 4. Economic structure of South Africa's informal economy, 2002

\begin{tabular}{|c|c|c|c|c|c|c|c|c|c|}
\hline & \multicolumn{3}{|c|}{ Share of total GDP (\%) } & \multirow{2}{*}{\multicolumn{2}{|c|}{$\begin{array}{l}\text { Informal sector's } \\
\text { share of national } \\
\text { total }(\%)\end{array}$}} & \multicolumn{4}{|c|}{ Informal trade shares and intensities (\%) } \\
\hline & \multirow[t]{2}{*}{$\begin{array}{l}\text { Formal } \\
\text { sector }\end{array}$} & \multirow[t]{2}{*}{$\begin{array}{l}\text { Informal } \\
\text { sector }\end{array}$} & \multirow[t]{2}{*}{ National } & & & \multirow[t]{2}{*}{$\begin{array}{l}\text { Total } \\
\text { exports }\end{array}$} & \multirow[t]{2}{*}{$\begin{array}{l}\text { Total } \\
\text { imports }\end{array}$} & \multirow[t]{2}{*}{$\begin{array}{l}\text { Exports/ } \\
\text { output }\end{array}$} & \multirow[t]{2}{*}{$\begin{array}{l}\text { Imports/ } \\
\text { demand }\end{array}$} \\
\hline & & & & GDP & Employment & & & & \\
\hline All sectors & 100.0 & 100.0 & 100.0 & 7.1 & 22.3 & 100.0 & 100.0 & 66.6 & 73.7 \\
\hline Agriculture & 3.9 & 9.3 & 4.3 & 15.2 & 43.9 & 8.6 & 6.2 & 82.5 & 82.6 \\
\hline & 20.7 & 9.1 & 19.9 & 3.3 & 12.6 & 12.0 & 53.8 & 56.4 & 89.1 \\
\hline Manufacturing & & & & & & & & & \\
\hline $\begin{array}{c}\text { Food } \\
\text { and beverages }\end{array}$ & 3.2 & 0.6 & 3.0 & 1.5 & 6.4 & 1.8 & 18.5 & 90.0 & 99.2 \\
\hline $\begin{array}{l}\text { Textiles } \\
\text { and clothing }\end{array}$ & 0.9 & 1.7 & 0.9 & 12.9 & 27.5 & 2.8 & 5.0 & 64.2 & 81.5 \\
\hline $\begin{array}{c}\text { Other } \\
\text { manufactures }\end{array}$ & 16.6 & 6.8 & 16.0 & 3.0 & 9.7 & 7.3 & 30.3 & 49.5 & 85.1 \\
\hline & 1.7 & 10.0 & 2.3 & 31.2 & 41.7 & 19.3 & 0.0 & 73.6 & 0.0 \\
\hline $\begin{array}{l}\text { Construction } \\
\text { Mining and } \\
\text { utilities }\end{array}$ & 12.1 & 0.0 & 11.2 & 0.0 & 0.0 & 0.0 & 5.6 & 0.0 & 100.0 \\
\hline Services & 61.6 & 71.6 & 62.3 & 8.2 & 20.3 & 60.1 & 34.4 & 65.2 & 60.1 \\
\hline trade ${ }^{\text {Retail }}$ & 10.2 & 41.5 & 12.4 & 23.7 & 43.1 & 30.0 & 1.0 & 61.2 & 6.7 \\
\hline & 0.9 & 1.6 & 1.0 & 11.3 & 20.1 & 1.5 & 1.0 & 60.7 & 60.5 \\
\hline Transport & 8.8 & 18.5 & 9.5 & 13.9 & 23.7 & 18.8 & 8.1 & 72.0 & 60.9 \\
\hline Business & 19.9 & 3.1 & 18.7 & 1.2 & 4.9 & 0.9 & 16.5 & 22.2 & 87.8 \\
\hline & 16.0 & 0.0 & 14.9 & 0.0 & 0.0 & 0.0 & 0.2 & 0.0 & 100.0 \\
\hline $\begin{array}{c}\text { Government } \\
\text { Other } \\
\text { services }\end{array}$ & 5.8 & 7.0 & 5.9 & 8.5 & 16.5 & 8.9 & 7.6 & 85.1 & 87.2 \\
\hline
\end{tabular}

Source: Own calculations using the 2002 South African Formal-Informal Sector Social Accounting Matrix.

Note: The "informal sector" in this table excludes the contribution of informally employed labor working in the formal sector (see Table 1).

The informal economy (narrowly defined) contributes 7.1 percent to South Africa's total GDP but generates 22.3 percent of total employment (see columns 4 and 5 in Table 4 ). This reflects the low wage rates and high labor intensity of the informal sector. The largest informal sectors are retail trade (41.5 percent), transport (18.5 percent), construction (10.0 percent), and subsistence agriculture (9.3 percent) (see column 2 in Table 4). Key informal manufacturing sectors include food processing and textiles. Food processing is an important traded product between the formal and informal sectors. Formal products supply almost all informal food consumption demand, and 90 percent of informal food production is supplied to the formal sector (see columns 8 and 9 in Table 4). Overall, the high import and export intensities reflect the considerable bidirectional trade that exists between the formal and informal economies. The higher import intensity is consistent with the trade deficit that the informal sector runs 
with the formal sector. Earlier in this section it was said that interregional trade covers around threequarters of the deficit. This means that around half of the overall deficit is covered by informal "exports" of retail trade, transport, and construction. This underlines the importance of informal services over informal agricultural and manufacturing producers.

"Informal households" are those earning income from the informal sector as well as from workers informally employed in the formal sector. We also include households with all members unemployed, since their nonzero consumption levels cannot be excluded from the economywide model, and because their demand patterns are closer to those of informal households. Based on this definition and according to IES2000, around two-thirds of South Africa's population is part of the informal economy (see Table 5). Informal households are typically poorer than formal households, with 66.6 percent of the informal population in the lowest five expenditure deciles, compared with 24.9 percent of the formal population. In contrast, only 7.8 percent of the informal population is in the highest two expenditure deciles.

In summary, SAFIM captures the initial economic structure of South Africa at a detailed sector level and across both factor and product markets. SAFIM's multiregional specification also allows it to capture the various formal-informal linkages depicted in the conceptual framework in Figure 1 (i.e., interregional trade, intersectoral labor migration, and social transfers). Finally, the model captures the four kinds of informal activities and employment identified in the typology in Table 1, including producers, traders, and workers employed without contracts or benefits. SAFIM's detailed structural and behavioral characteristics, and its calibration to observed South African data, make it an ideal tool for examining socioeconomic policies.

Table 5. Household population patterns, 2000

\begin{tabular}{llll}
\hline & $\begin{array}{l}\text { Formal } \\
\text { households }\end{array}$ & $\begin{array}{l}\text { Informal } \\
\text { households }\end{array}$ & $\begin{array}{l}\text { All } \\
\text { households }\end{array}$ \\
\hline Population (1,000s) & 17,404 & 26,291 & 43,694 \\
All expenditure deciles (\%) & 100.0 & 100.0 & 100.0 \\
Deciles 1-5 & 24.9 & 66.6 & 50.0 \\
Deciles 6-8 & 34.6 & 26.9 & 30.0 \\
Deciles 9 & 17.6 & 5.0 & 10.0 \\
Deciles 10 & 20.9 & 2.8 & 10.0 \\
\hline
\end{tabular}

Source: Own calculations using 2000 Income and Expenditure Survey (StatsSA 2000)

Note: "Informal households" include all households reporting earnings from informal employment as well as households where all members are unemployed.Some columns do not add to 100 percent due to rounding errors. 


\section{THREE POLICY SIMULATIONS}

SAFIM is used to assess the effectiveness of three different policies in generating employment and raising household incomes. The policies are trade liberalization, wage subsidies, and unconditional cash transfers. We also consider how previous national-level assessments of these policies may have concealed differential outcomes for formal and informal economies.

\section{Trade Liberalization}

South Africa underwent rapid trade liberalization during the 1990s. At the same time both unemployment and poverty worsened. Further relaxation of trade restrictions has therefore been the subject of much debate. A number of sector studies find that liberalization reduced industrial employment, albeit only slightly (see, for example, Bhorat 1999; Edwards 2001). Economywide studies find divergent outcomes for industry and services but also indicate a net decline in national employment (Thurlow 2007; Hérault and Thurlow forthcoming). Within this context, we use SAFIM to simulate the impact of eliminating all remaining import tariffs in 2002. Table 6 shows the initial rates and tariff collections. We replace lost government revenues by raising direct tax rates in order to maintain public recurrent consumption spending at its initial level. Tax rate increases include both corporate and personal income tax rates and are proportional to initial rates (i.e., increasing tax rates produces regressive outcomes).

Table 6. Initial tariff rates and collections, 2002

\begin{tabular}{llll}
\hline & $\begin{array}{l}\text { Tariff } \\
\text { collection } \\
\text { share }(\%)\end{array}$ & $\begin{array}{l}\text { Foreign } \\
\text { import } \\
\text { value share } \\
(\%)\end{array}$ & $\begin{array}{l}\text { Tariff } \\
\text { collection } \\
\text { rate }(\%)\end{array}$ \\
\hline Total GDP & 100.0 & 100.0 & 2.8 \\
Agriculture & 2.9 & 2.2 & 3.7 \\
Manufacturing & 95.9 & 70.2 & 3.9 \\
Food and beverages & 5.0 & 2.5 & 5.6 \\
\hline Textiles and clothing & 21.0 & 3.2 & 18.5 \\
Other manufactures & 69.9 & 64.5 & 3.1 \\
Construction & 0.0 & 0.1 & 0.0 \\
Mining and utilities & 0.0 & 11.2 & 0.0 \\
\hline Services & 1.2 & 16.2 & 0.2 \\
Retail trade & 0.0 & 0.3 & 0.0 \\
Restaurants & 0.0 & 2.8 & 0.0 \\
Transport & 0.0 & 3.9 & 0.0 \\
Business & 1.1 & 2.5 & 1.3 \\
Government & 0.0 & 1.2 & 0.0 \\
Other services & 0.0 & 6.7 & 0.0 \\
\hline
\end{tabular}

Source: Own calculations using the 2002 South African Formal-Informal Sector Social Accounting Matrix Note: Some columns do not add to 100 percent due to rounding errors.

Table 7 shows the changes in production under the three policy simulations. Trade liberalization reduces tariffs on South Africa's foreign imports, which reduces import prices and raises demand for imported products. The highest tariffs in 2002 were on textiles and clothing. Therefore, those sectors face the largest increase in import competition when tariffs are eliminated, with the production of textiles and clothing declining by 4.7 percent (see column 3 in Table 7). Moreover, textile producers in both the formal and informal sectors are adversely affected by cheaper imported products. The overall increase in imports has macroeconomic implications, since it places pressure on the current account balance, which is 
assumed to be fixed in foreign currency. The real exchange rate therefore depreciates by 2 percent in order to offset some of the increase in foreign import demand and encourage foreign exports. This depreciation causes a slight increase in production among nontextile manufacturing sectors, such as processed foods, metals, and wood products. However, because it is the formal sector that engages in foreign exports and not informal producers, formal producers of processed foods and other manufactured goods benefit. Hence, whereas formal production in these sectors increases, production declines for informal producers, who face higher import competition without any improved access to foreign export markets.

Table 7. Changes in production under alternative policy simulations

\begin{tabular}{|c|c|c|c|c|c|c|c|c|c|}
\hline & \multicolumn{9}{|c|}{ Change in gross domestic product from base value (\%) } \\
\hline & \multicolumn{3}{|c|}{ Trade liberalization } & \multicolumn{3}{|c|}{ Wage subsidy } & \multicolumn{3}{|c|}{ Unconditional cash transfer } \\
\hline & $\begin{array}{l}\text { Formal } \\
\text { sector }\end{array}$ & $\begin{array}{l}\text { Informal } \\
\text { sector }\end{array}$ & National & $\begin{array}{l}\text { Formal } \\
\text { sector }\end{array}$ & $\begin{array}{l}\text { Informal } \\
\text { sector }\end{array}$ & National & $\begin{array}{l}\text { Formal } \\
\text { sector }\end{array}$ & $\begin{array}{l}\text { Informal } \\
\text { sector }\end{array}$ & National \\
\hline Total GDP & 0.32 & -1.13 & 0.21 & 1.47 & -0.07 & 1.36 & 0.01 & 2.01 & 0.15 \\
\hline Agriculture & 0.25 & -0.17 & 0.19 & 0.41 & -0.27 & 0.31 & 0.79 & 2.30 & 1.02 \\
\hline & 0.17 & -7.87 & -0.09 & 1.94 & -7.25 & 1.64 & 0.13 & 1.69 & 0.18 \\
\hline $\begin{array}{l}\text { Manufacturing } \\
\text { Food and }\end{array}$ & 0.06 & 112 & & 197 & & & & & \\
\hline beverages & 0.00 & -1.12 & 0.00 & 1.97 & -9.95 & 1.80 & 1.18 & 1.02 & 1.10 \\
\hline $\begin{array}{l}\text { Textiles } \\
\text { and clothing }\end{array}$ & -4.57 & -5.33 & -4.67 & 5.36 & -5.80 & 3.92 & 1.45 & 5.21 & 1.94 \\
\hline $\begin{array}{c}\text { Other } \\
\text { manufactures }\end{array}$ & 0.44 & -9.13 & 0.15 & 1.76 & -7.36 & 1.48 & -0.15 & 0.82 & -0.12 \\
\hline & -0.20 & -3.51 & -1.23 & 3.02 & -1.17 & 1.71 & -0.57 & -1.05 & -0.72 \\
\hline $\begin{array}{l}\text { Construction } \\
\text { Mining and } \\
\text { utilities }\end{array}$ & 1.34 & 0.00 & 1.34 & 1.99 & 0.00 & 1.99 & 0.20 & 0.00 & 0.20 \\
\hline Services & 0.18 & -0.06 & 0.16 & 1.24 & 1.02 & 1.22 & -0.11 & 2.45 & 0.10 \\
\hline Retail & -0.24 & 0.00 & -0.19 & 2.47 & 1.24 & 2.18 & 0.28 & 2.45 & 0.79 \\
\hline trade & 0.57 & -0.41 & 0.46 & 6.42 & 0.77 & 5.78 & 0.38 & 5.17 & 0.92 \\
\hline Restaurants & & & & & & & & & \\
\hline Transport & 0.33 & -0.02 & 0.28 & 1.59 & 0.85 & 1.49 & 0.46 & 2.57 & 0.76 \\
\hline Business & -0.14 & -0.61 & -0.15 & 1.39 & -0.01 & 1.37 & 0.01 & 2.16 & 0.03 \\
\hline & 0.74 & 0.00 & 0.74 & -0.58 & 0.00 & -0.58 & -0.95 & 0.00 & -0.95 \\
\hline $\begin{array}{c}\text { Government } \\
\text { Other } \\
\text { services }\end{array}$ & 0.23 & -0.23 & 0.19 & 2.18 & 0.74 & 2.06 & 0.22 & 1.65 & 0.34 \\
\hline
\end{tabular}

Source: Results from the South African Formal-Informal Model (SAFIM).

Note: The "informal sector" in this table excludes the contribution of informally employed labor working in the formal sector (see Table 1).

Falling informal production reduces employment among informal producers (see column 2 in Table 8). This is especially pronounced for semiskilled informal producers and workers, who are more intensively engaged in manufacturing. However, the increase in production within the formal sector (driven by expanding exports) generates additional jobs for formal workers, primarily for high-skilled and unskilled workers in the service sectors. There is also increased demand for informally employed workers in the formal sector, although this benefits mainly lower-skilled workers. Finally, the decline in informal production and foreign import prices encourages informal consumers to become more reliant on foreign 
imported goods. This shift in consumer preferences increases the amount of trade between the informal and formal sectors, thus benefiting informal traders, who collect fixed transaction margins based on the volume of trade. Thus, whereas employment for informal producers falls under trade liberalization, lowerskilled informal traders experience a slight increase in employment.

Table 8. Changes in employment under alternative policy simulations

\begin{tabular}{|c|c|c|c|c|}
\hline & \multirow{2}{*}{$\begin{array}{l}\text { Base } \\
\text { employment } \\
(1,000 \mathrm{~s})\end{array}$} & \multicolumn{3}{|c|}{ Change in employment from base (\%) } \\
\hline & & $\begin{array}{l}\text { Trade } \\
\text { liberalization }\end{array}$ & Wage subsidy & $\begin{array}{l}\text { Unconditiona } \\
\text { cash transfer }\end{array}$ \\
\hline Total employment & 10,556 & -0.13 & 3.60 & 1.58 \\
\hline Skilled & 2,048 & 0.00 & 0.00 & 0.00 \\
\hline Semiskilled & 4,826 & -0.42 & 6.03 & 1.28 \\
\hline Unskilled & 3,682 & 0.17 & 2.42 & 2.83 \\
\hline Formal workers & 6,754 & 0.42 & 5.63 & 0.49 \\
\hline Skilled & 1,898 & 0.14 & -0.03 & -0.33 \\
\hline Semiskilled & 3,524 & 0.52 & 8.77 & 0.63 \\
\hline Unskilled & 1,332 & 0.57 & 5.41 & 1.26 \\
\hline Informally employed & 1,451 & 0.43 & 0.53 & 0.82 \\
\hline Skilled & 0 & 0.00 & 0.00 & 0.00 \\
\hline Semiskilled & 357 & 0.05 & -0.08 & 0.79 \\
\hline Unskilled & 1,095 & 0.55 & 0.73 & 0.83 \\
\hline Informal traders & 805 & 0.01 & 2.61 & 5.29 \\
\hline Skilled & 18 & -0.45 & 2.23 & 4.72 \\
\hline Semiskilled & 265 & 0.02 & 2.61 & 5.31 \\
\hline Unskilled & 522 & 0.02 & 2.61 & 5.31 \\
\hline Informal producers & 1,545 & -3.16 & -1.86 & 5.11 \\
\hline Skilled & 132 & -1.94 & 0.17 & 4.09 \\
\hline Semiskilled & 681 & -5.73 & -3.59 & 3.34 \\
\hline Unskilled & 733 & -0.99 & -0.61 & 6.94 \\
\hline
\end{tabular}

Source: Results from the South African Formal-Informal Model (SAFIM).

Note: "Formal workers" refers to formally employed workers in the formal sector; "informally employed" refers to informally employed workers in the formal sector (see Table 1). Some columns do not add to 100 percent due to rounding errors.

Overall, trade liberalization causes employment to fall slightly, despite an overall increase in national GDP. This is consistent with the findings of previous studies (see, for example, Thurlow 2007). However, national results hide divergent outcomes for formal and informal sectors. Total informal production declines significantly, leading to a similar decline in informal employment. In contrast, formal sector producers and their workers, especially in the service sectors, benefit from improved access to foreign export markets, which more than offsets the losses caused by increased import competition. Total formal GDP therefore rises and creates new formal sector employment opportunities. The opening of South Africa's economy since the early 1990s may therefore have contributed to the small size of South Africa's informal sector relative to the formal economy. Moreover, model results indicate that trade liberalization alters the composition of the informal economy. There is a shift in employment away from informal producers toward informal traders and workers informally employed in the formal sector. This is consistent with the observation that South Africa has a small informal producer sector and a disproportionately large informal trader sector (Blaauw 2005).

Table 9 shows changes in household incomes following trade liberalization. The income changes include a 6 percent increase in direct taxes that is needed to offset lost revenue from eliminating import tariffs, which amounts to 9.6 billion rand (i.e., about 1 percent of national GDP in 2002). This tax increase 
affects only formal households and is based on tax collection rates. Overall there is a slight decline in real household disposable incomes due to falling employment. That offsets lower consumer prices and slightly higher national GDP. However, impacts across household groups differ significantly. Previous studies find that trade liberalization benefited households in the middle of the income distribution (Thurlow 2007). Our results are consistent, since incomes rise for national deciles 5 through 9 , but fall for other household groups. Disposable incomes for the highest expenditure decile fall substantially because most households in this group are in the formal sector and face the highest marginal tax rates. They therefore bear the brunt of the required revenue-replacing tax increase. However, there are different distributional implications from trade liberalization for formal and informal households. The informal households at the top of the income distribution benefit the most from trade liberalization. That is because those informal households have fewer unemployed members compared with lower-income informal households. They are also not subject to the increase in direct taxes, and are less affected by the drop in employment for semiskilled workers. Thus, while the bottom nine deciles for formal households experience rising incomes, the bottom eight informal deciles experience declining incomes. Thus, the decline in incomes among poorer households observed at the national level is driven by falling informal household incomes.

\section{Table 9. Changes in incomes under alternative policy simulations}

\begin{tabular}{clll}
\hline & \multicolumn{3}{l}{ Change in income from base (\%) } \\
\cline { 2 - 4 } & $\begin{array}{l}\text { Trade } \\
\text { liberalization }\end{array}$ & $\begin{array}{l}\text { Wage } \\
\text { subsidy }\end{array}$ & $\begin{array}{l}\text { Unconditional } \\
\text { cash transfer }\end{array}$ \\
\hline All households & -0.29 & 1.51 & 1.39 \\
Deciles 1-5 & -0.09 & 2.13 & 24.13 \\
Deciles 6-8 & 0.09 & 2.68 & 5.29 \\
Deciles 9 & 0.15 & 2.44 & 1.14 \\
Deciles 10 & -0.53 & 0.89 & -1.81 \\
Formal households & -0.31 & 1.59 & -0.80 \\
Deciles 1-5 & 0.24 & 3.23 & 6.47 \\
Deciles 6-8 & 0.30 & 3.49 & 2.44 \\
Deciles 9 & 0.17 & 2.68 & 0.34 \\
Deciles 10 & -0.56 & 0.88 & -2.08 \\
Informal households & -0.21 & 0.99 & 16.15 \\
Deciles 1-5 & -0.46 & 0.84 & 44.85 \\
Deciles 6-8 & -0.39 & 0.84 & 11.76 \\
Deciles 9 & 0.02 & 1.14 & 5.52 \\
Deciles 10 & 0.15 & 1.25 & 4.04 \\
\hline
\end{tabular}

Source: Results from the South African Formal-Informal Model (SAFIM).

Note: Incomes are post-tax (i.e., disposable); "informal households" refers to all households reporting earnings from informal employment as well as households wherein all members are unemployed.

In summary, trade liberalization has different implications for South Africa's formal and informal sectors. It substantially reduces informal employment by raising import competition without providing additional opportunities for informal producers to access foreign export markets. In contrast, formal producers are better able to take advantage of the new foreign market opportunities, and their production expands as a result. Trade liberalization also alters the composition of the informal sector, by reducing product market space for informal producers, increasing opportunities for informal traders, and encouraging informal workers to seek casual employment in the formal sector. Ultimately, it is the adverse effect that trade liberalization has on the informal sector that reduces total employment in spite of new employment opportunities in the formal sector. This highlights the need for policies to support further employment creation and raise incomes among poor households. 


\section{Wage Subsidy}

There is ongoing debate in South Africa regarding the effectiveness of a wage subsidy to reduce unemployment. Two studies have examined this policy option using national CGE models (Pauw and Edwards 2006; Go et al. 2009). Those studies find that a wage subsidy targeted toward lower-skilled workers raises the overall level of employment, despite the need for compensating tax increases and possible inflexibilities in the labor market. In this section we provide a 7 percent wage subsidy to all semiskilled and unskilled workers in the formal sector, which is only slightly below the 10 percent wage subsidy simulated in previous studies. We target a lower wage subsidy so that the required increase in direct taxes to maintain a balanced fiscal budget is the same as under the previous trade liberalization scenario.

The wage subsidy reduces the cost of workers for firms and increases demand for labor. There is consequently a substantial increase in employment for semiskilled and unskilled labor in the formal sector (see column 3 in Table 8). There is also a modest shift in demand away from skilled workers and capital.6 The largest increases in employment are within the more labor-intensive sectors, which benefit the most from the subsidy. Those sectors include textiles and clothing and construction, whose formal sector production expands significantly under this policy simulation (see column 4 in Table 7). Overall, national employment rises by 3.6 percent as a result of the wage subsidy.

Again, the national results hide differential outcomes for the formal and informal sectors. This is because the wage subsidy reduces the cost of production in the formal sector but does not benefit informal producers. As a result, the price of formal products declines relative to informal products. This causes consumers to shift demand toward formal products at the expense of informal producers, whose production declines significantly (see column 5 in Table 7). It also encourages greater export growth, which benefits only formal sector firms. Informal workers therefore migrate toward those sectors that face a smaller penetration of formal sector products and fewer opportunities for export displacement. That includes much of the service sector, where trade intensities are lowest (see the final two columns of Table 4). Despite this migration to services, there is still a sharp overall decline in employment among informal producers. Falling formal sector prices and increased trade with the formal sector does, however, benefit informal traders. Increased formal sector production also benefits workers who are informally employed in the formal sector, despite the substantial overall shift in labor demand toward formally employed workers (i.e., who are eligible to receive the subsidy).

Even though informal production declines slightly, informal households' disposable real incomes still rise as a result of the wage subsidy. This is partly because of the offsetting increase in employment for traders and informally employed workers in the formal sector. However, the main driver behind rising informal incomes is the sharp decline in consumer prices caused by the lower cost of production. This result suggests that if producers pass the cost reduction on to consumers, then real incomes will rise even among nonrecipient households in the informal sector. Again, the informal households toward the higher end of the income distribution benefit more than lower-income informal households. This is because semiskilled workers in the informal sector are more heavily concentrated among higher-income informal households. In contrast, higher-income formal sector households are more reliant on high-skilled workers, who did not receive the wage subsidy in our simulation. Moreover, such higher-income households experience the largest increases in direct taxes in order to cover the cost of the subsidy. Consequently, it is lower-income formal sector households that benefit the most from the targeted wage subsidy.

In summary, a targeted wage subsidy greatly expands employment and real incomes but favors households toward the middle of the national income distribution. This is because informal producers face increased competition from subsidized formal sector producers. This encourages a shift in the composition of informal employment toward traders and casual employment. Thus, even though our results are consistent with previous national-level studies, they again highlight the importance of taking

6 Our simulation is broadly equivalent to that of Pauw and Edwards (2006) and to the "medium" case simulation presented in Go et al. (2009). 
formal-informal linkages into account, as well as considering the effects of employment policies on both labor and product markets.

\section{Unconditional Cash Transfers}

An alternative policy to the wage subsidy that has also received considerable attention in South Africa is an unconditional cash transfer, also called a basic income grant. Such transfers would be paid to all South Africans irrespective of age, work status, or income level. The policy would be financed by increased taxes. Numerous studies have examined the impact of the cash transfer on household welfare. Thurlow (2002) uses a CGE model to estimate the economywide impact of providing a 100 rand per person per month transfer to all South Africans. In this section we simulate a smaller transfer of 60 rand per month, since this would already involve a direct tax rate increase twice the size of that in the previous simulations (i.e., 13 percent instead of 6 percent).

Our results are consistent with those from previous studies. The cash transfer increases disposable incomes for all households, except for formal sector households in the highest expenditure decile (see the final column of Table 9). Those households are hit with the largest increases in tax rates in order to maintain a balanced fiscal budget. Given their importance in determining the absolute level of formal sector consumption spending, the required increase in taxes more than offsets the additional income from the cash transfer, causing real formal sector incomes to fall. The transfer also has different implications for households within the informal economy. More specifically, the value of the grant as a percentage of current incomes is much larger for lower-income households. Real per capita incomes therefore increase by 44.9 percent for the bottom five informal deciles, compared with only 4.0 percent for the highest informal decile.

Large increases in informal household incomes generate additional demand for informally produced products, especially processed foods, informal restaurants, and transport services (see column 8 in Table 7). This increase in demand generates additional employment and marketing opportunities for informal producers, whose employment rises substantially. The increase in income also generates additional demand for imported and formal sector products, which benefits informal traders. Overall, the unconditional cash transfer raises national production and employment, despite some slight adverse implications for formal sector production. However, the fiscal burden of the cash transfer is significant, representing more than 2 percent of national GDP in the current simulation, and almost 5 percent for the 120 rand per capita grant that is currently being debated. Our analysis indicates that there would have to be a substantial increase in direct taxes, with severe implications for higher-income households. We do not consider the effects of the grant on capital flight, declining foreign investment, and tax evasion, any of which would increase the necessary tax hikes and could possibly undermine long-term economic growth. However, despite its relatively small and possibly overestimated impact on national production, the results from our analysis do confirm the strongly pro-poor outcomes of an unconditional cash transfer. 


\section{CONCLUSION}

Unemployment is one of South Africa's most pressing social challenges. Existing studies identify the underperformance of the formal sector and the existence of barriers to entry in the informal sector as the primary explanations for high unemployment. Our study has extended that literature by considering the linkages between the formal and informal economies. We adopted a broader view of informal employment, by including workers who are informally employed in the formal sector. We found that this explains some of South Africa's disproportionately small informal sector. However, even under the broader view, our results indicated that most of the interactions between the formal and informal sectors occur within product markets. We therefore adopted an economywide perspective and accounted for formal-informal interactions in both factor and product markets. Finally, we considered differences in behavior among informal activities. Drawing on a typology of informal employment, we developed a multiregion CGE model that is empirically calibrated to the structure and behavior of South African formal and informal economies. We used the model to examine three policies designed to expand production and employment.

Model results indicate that whereas trade liberalization reduces national employment, it has sharply different implications for formal and informal sectors. Formal sector production and employment expands, in part due to enhanced production efficiency and improved export opportunities. In contrast, increased import competition undermines informal producers and encourages informal workers to move into trading and casual employment in the formal sector. This result suggests that past trade liberalization may explain some of the small size of South Africa's informal sector, as well as its concentration within trading rather than production. Whereas formal sector households are the main beneficiaries of trade liberalization, lower import prices also benefit higher-income informal households. The overall effect of liberalization is, however, a widening of the income gap between rich and poor households, and between formal and informal sectors. Further trade liberalization is therefore unlikely to generate the employment and income opportunities needed to reduce unemployment significantly in South Africa.

We also examined the impact of introducing a wage subsidy to stimulate labor demand, and of using an unconditional cash transfer to raise incomes directly. A wage subsidy raises employment substantially at the national level. However, it also favors formal sector producers, whose lower cost of production allows them to reduce their market prices. This heightens competition between formal and informal producers in domestic product markets and causes a substantial decline in informal employment. Increased trade with the formal sector does, however, benefit informal traders. A wage subsidy would therefore further narrow South Africa's informal sector toward the greater trading of formal and imported products. In contrast, an unconditional cash transfer stimulates demand for informally produced products and causes a substantial increase in informal producer employment, while also benefiting informal traders. The cash transfer also has the largest positive impact on lower-income households' incomes and helps narrow the income gap between formal and informal households. However, the large size of the cash transfer requires substantial increases in tax rates, which adversely affect formal sector households, especially at the higher end of the income distribution. Moreover, the cash transfer is less effective at stimulating national production than a wage subsidy.

Beyond their policy implications, our findings confirm the need to assess the differential implications of policies on formal and informal economies. This is because the results of previous studies have hidden sharply divergent outcomes for formal and informal enterprises and households, which should ideally be considered when assessing alternative socioeconomic policies. Finally, our results highlight the importance of capturing differences in behavior across the full spectrum of informal activities, as well as the need to consider both labor and production market conditions when designing policies to address South Africa's unemployment challenge. 


\section{APPENDIX: MATHEMATICAL SPECIFICATION OF THE MODEL}

Table A.1. Model equations

\begin{tabular}{|c|c|c|}
\hline Prices & & \\
\hline Import price & $P R_{w r c}=p w m_{r c} \cdot\left(1+t m_{r c}\right) \cdot E X R$ & 1 \\
\hline Export price & $P R_{r w c}=p w e_{r c} \cdot E X R$ & 2 \\
\hline Domestic sales price & $P Q_{r c} \cdot\left(1-t q_{r c}\right) \cdot Q Q_{r c}=\sum_{t} P R M_{t r c} \cdot Q R_{t r c}$ & 3 \\
\hline Activity price & $\sum_{a=c} P A_{r a} \cdot Q A_{r a}=\sum_{t} P R_{r t c} \cdot Q R_{r t c}$ & 4 \\
\hline Value-added price & $P A_{r a} \cdot Q A_{r a}=P V_{r a} \cdot Q V_{r a}+\sum_{c} P Q_{r c} \cdot Q N_{r c a}$ & 5 \\
\hline Price margin & $+\sum_{c^{\prime}} i c r_{t t^{\prime} c c^{\prime}} \cdot P R_{t t^{\prime} c}$ & 6 \\
\hline Consumer price index & $C P I=\sum_{r c} c w t s_{r c} \cdot P Q_{r c}$ & 7 \\
\hline Domestic price index & $D P I=\sum_{r c} d w t s_{r c} \cdot P R_{r r c}$ & 8 \\
\hline \multicolumn{3}{|l|}{ Production and trade } \\
\hline Intermediate demand & $\theta_{r c a}^{n} \cdot Q A_{r a}$ & 9 \\
\hline Gross output & $Q V_{r a}=\theta_{r a}^{v} \cdot Q A_{r a}$ & 10 \\
\hline Production function & $\left.\cdot Q F_{r f a}^{-\rho_{r a}^{v}}\right)^{-1 / \rho_{r a}^{v}}$ & 11 \\
\hline $\begin{array}{l}\text { Production function } \\
\text { first-order condition }\end{array}$ & $W F_{r f} \cdot W D_{r f a}-w s_{r f a}=P V_{r a} \cdot Q V_{r a} \cdot \sum_{f^{\prime}}\left(\delta_{r f^{\prime} a}^{v} \cdot Q F_{r f^{\prime} a}^{-\rho_{r a}^{v}}\right)^{-1} \cdot \delta_{r f a}^{v} \cdot Q F_{r f a}^{-\rho_{r a}^{v}-1}$ & 12 \\
\hline $\begin{array}{l}\text { Export transformation } \\
\text { function }\end{array}$ & $\sum_{a=c} Q A_{r a}=\alpha_{r c}^{t} \cdot \sum_{t}\left(\delta_{r t c}^{t} \cdot Q R_{r t c}^{\rho_{r c}^{t}}\right)^{1 / \rho_{r c}^{t}}$ & 13 \\
\hline $\begin{array}{l}\text { Export transformation } \\
\text { first-order condition }\end{array}$ & $P R_{r t c}=\sum_{a=c} P A_{r a} \cdot Q A_{r a} \cdot \sum_{t^{\prime}}\left(\delta_{r t^{\prime} c}^{t} \cdot Q R_{r t^{\prime} c}^{\rho_{r c}^{t}}\right)^{-1} \cdot \delta_{r t c}^{t} \cdot Q R_{r t c}^{\rho_{r c}^{t}-1}$ & 14 \\
\hline $\begin{array}{l}\text { Nonexport/domestic } \\
\text { commodities }\end{array}$ & $\sum_{a=c} Q A_{r a}=\sum_{t} Q R_{r t c}$ & 15 \\
\hline $\begin{array}{l}\text { Import substitution } \\
\text { function }\end{array}$ & $Q Q_{r c}=\alpha_{r c}^{q} \cdot \sum_{t}\left(\delta_{t r c}^{q} \cdot Q R_{t r c}^{-\rho_{r c}^{q}}\right)^{-1 / \rho_{r c}^{q}}$ & 16 \\
\hline $\begin{array}{l}\text { Import substitution } \\
\text { first-order condition }\end{array}$ & $P R M_{t r c}=P Q_{r c} \cdot\left(1-t q_{r c}\right) \cdot Q Q_{r c} \cdot \sum_{t^{\prime}}\left(\delta_{t^{\prime} r c}^{q} \cdot Q R_{t^{\prime} r c}^{-\rho_{r c}^{q}}\right)^{-1} \cdot \delta_{t r c}^{q} \cdot Q R_{t r c}^{-\rho_{r c}^{q}-1}$ & 17 \\
\hline
\end{tabular}




\section{Table A.1. Continued}

\begin{tabular}{|c|c|c|}
\hline \multicolumn{3}{|c|}{ Production and trade continued } \\
\hline $\begin{array}{l}\text { Nonimport or domestic } \\
\text { commodities }\end{array}$ & $Q Q_{r c}=\sum_{t} Q R_{t r c}$ & 18 \\
\hline Transaction costs & $Q T_{r c}=\sum_{t c^{\prime}} i c r_{t r c^{\prime} c} \cdot Q R_{t r c^{\prime}}$ & 19 \\
\hline \multicolumn{3}{|l|}{ Factors and institutions } \\
\hline Factor incomes & $Y F_{f}=\sum_{r a} W F_{r f} \cdot W D_{r f a} \cdot Q F_{r f a}$ & 20 \\
\hline Household incomes & $Y H_{r h}=\sum_{f} \theta_{r h f}^{h f} \cdot\left(1-t f_{r f}\right) \cdot Y F_{r f}+g h_{r h} \cdot p o p_{r h} \cdot C P I$ & 21 \\
\hline Consumption demand & $P Q_{r c} \cdot Q H_{r c h}=\beta_{r c h}^{h} \cdot\left(1-s h_{r h}\right) \cdot\left(1-t h_{r h}\right) \cdot Y H_{r h}$ & 22 \\
\hline Government revenues & $\begin{array}{c}Y G=\sum_{r h} t h_{r h} \cdot Y H_{r h}+\sum_{r f} t f_{r f} \cdot Y F_{r f}+\sum_{r c} t q_{r c} \cdot P Q_{r c} \cdot Q Q_{r c} \\
+\sum_{r w c} t m_{r c} \cdot p w m_{r c} \cdot Q R_{w r c} \cdot E X R\end{array}$ & 23 \\
\hline Investment demand & $Q I_{r c}=q i n v_{r c} \cdot I A D J$ & 24 \\
\hline Government demand & $Q G_{r c}=q g o v_{r c} \cdot G A D J$ & 25 \\
\hline \multicolumn{3}{|l|}{ System constraints } \\
\hline $\begin{array}{l}\text { Product market } \\
\text { equilibrium }\end{array}$ & $Q Q_{r c}=\sum_{a} Q N_{r c a}+\sum_{h} Q H_{r c h}+Q G_{r c}+Q I_{r c}+Q T_{r c}$ & 26 \\
\hline $\begin{array}{l}\text { Factor market } \\
\text { equilibrium }\end{array}$ & $Q F S_{f}=\sum_{r a} Q F_{r f a}$ & 27 \\
\hline Government balance & $\sum_{r c} P Q_{r c} \cdot Q G_{r c}+\sum_{r h} g h_{r h} \cdot p o p_{r h} \cdot C P I+\sum_{r f a} w s_{r f a} \cdot Q F_{r f a}=(1-s g) \cdot Y G$ & 28 \\
\hline $\begin{array}{l}\text { Savings/investment } \\
\text { balance }\end{array}$ & $\sum_{r c} P Q_{r c} \cdot Q I_{r c}=\sum_{r h} s_{r h} \cdot\left(1-t h_{r h}\right) \cdot Y H_{r h}+F S A V \cdot E X R+s g \cdot Y G$ & 29 \\
\hline $\begin{array}{l}\text { Current account } \\
\text { balance }\end{array}$ & $F S A V=\sum_{r w c}\left(p w m_{r c} \cdot Q R_{w r c}-p w e_{r c} \cdot Q R_{r w c}\right)$ & 30 \\
\hline Regional balance & $R S A V_{r}=\sum_{r^{\prime} c}\left(P R_{r^{\prime} r c} \cdot Q R_{r^{\prime} r c}-P R_{r r^{\prime} c} \cdot Q R_{r r^{\prime} c}\right)$ & 31 \\
\hline
\end{tabular}


Table A.2. Model sets, parameters, and variables

\begin{tabular}{|c|c|c|c|}
\hline \multicolumn{2}{|c|}{ Sets or indexes } & \multicolumn{2}{|c|}{ Sets or indexes } \\
\hline$a$ & Activities & $t$ & All regions (domestic and foreign) \\
\hline$c$ & Commodities & $r$ & Domestic regions (formal and informal) \\
\hline$f$ & Factor (labor and capital) & $w$ & Foreign region (rest of world) \\
\hline & Households & & \\
\hline \multicolumn{2}{|c|}{ Parameters or exogenous variables } & \multicolumn{2}{|c|}{ Parameters or exogenous variables } \\
\hline$\alpha^{q}$ & Import substitution shift parameter & $g h$ & Per capita transfer from government \\
\hline$\alpha^{t}$ & Export transformation shift parameter & $i c r$ & Transaction cost margin (from $t$ to $t^{\prime}$ ) \\
\hline$\alpha^{v}$ & Production function shift parameter & pop & Household population \\
\hline$\beta^{h}$ & Average household budget share & pwe & World export price \\
\hline$\delta^{q}$ & Import substitution share parameter & pwm & World import price \\
\hline$\delta^{t}$ & Export transformation share parameter & qgov & Base government demand quantity \\
\hline$\delta^{v}$ & Production function share parameter & qinv & Base investment demand quantity \\
\hline$\theta^{h f}$ & Household factor income share & $s g$ & Government savings rate \\
\hline$\theta^{n}$ & Intermediate input technology coefficient & $\operatorname{sh}$ & Household savings rate \\
\hline$\theta^{v}$ & Value-added technology coefficient & $t f$ & Factor tax rate \\
\hline$\rho^{q}$ & Import substitution elasticity & th & Household direct tax rate \\
\hline$\rho^{t}$ & Export transformation elasticity & $t m$ & Import tariff rate \\
\hline$\rho^{v}$ & Factor substitution elasticity & $t q$ & Sales tax rate \\
\hline cwts & Consumer price index weight & $w s$ & Wage subsidy value \\
\hline$d w t s$ & Domestic price index weight & & \\
\hline \multicolumn{2}{|c|}{ Endogenous variables } & \multicolumn{2}{|c|}{ Endogenous variables } \\
\hline$C P I$ & Consumer price index & $Q G$ & Government demand quantity \\
\hline$D P I$ & Domestic price index & $Q H$ & Household consumption demand quantity \\
\hline$E X R$ & Exchange rate & $Q I$ & Investment demand quantity \\
\hline$G A D J$ & Government demand adjustment factor & $Q N$ & Intermediate input quantity \\
\hline FSAV & Foreign savings & $Q Q$ & Composite quantity \\
\hline$I A D J$ & Investment demand adjustment factor & $Q R$ & Domestic supply quantity \\
\hline$P A$ & Activity price & $Q T$ & Transaction margin quantity \\
\hline$P Q$ & Composite price & $Q V$ & Value-added quantity \\
\hline$P R$ & Domestic supply price (without margin) & $W D$ & Sector and region wage distortion \\
\hline$P R M$ & Domestic supply price (with margin) & $W F$ & Economywide average wage rate \\
\hline$P V$ & Value-added price & $Y F$ & Total factor income \\
\hline$Q A$ & Activity quantity & $Y G$ & Total government income \\
\hline$Q F$ & Factor demand quantity & $Y H$ & Total household income \\
\hline
\end{tabular}




\section{REFERENCES}

Berry, A., M. von Blottnitz, R. Cassim, A. Kesper, B. Rajaratnam, and D. E. N van Seventer. 2002. The economics of SMMEs in South Africa. Pretoria, South Africa: Trade and Industrial Policy Strategies. http://www.tips.org.za/files/506.pdf. Accessed December 29, 2009.

Bhorat, H. 1999. Decomposing sectoral employment trends in South Africa. Paper presented at the Trade and Industrial Policy Strategies Annual Forum, 19-22 September, Muldersdrift, South Africa.

Blaauw, P. F. 2005. The dynamics of the informal sector in South Africa: A case study of day laborers in Pretoria. Paper presented at the biennial conference of the Economic Society of South Africa, September 7-9, 2005, Durban, South Africa.

Casale, D., C. Muller, and D. Posel. 2004. Two million net new jobs: A reconsideration of the rise in employment in South Africa, 1995-2003. South African Journal of Economics 72 (5): 978-1002.

Devey, R., C. Skinner, and I. Valodia. 2003. Informal economy employment data in South Africa: A critical analysis. Paper presented at the Development Policy Research Unit's Forum 2003, September 8-10, Johannesburg, South Africa.

Edwards, L. 2001. Globalisation and the occupational structure of employment in South Africa. South African Journal of Economics 69 (1): 40-71.

Go, D., M. Kearney, V. Korman, S. Robinson, and K. Thierfelder. 2009. Wage subsidy and labor market flexibility in South Africa. Policy Research Working Paper 4871, Africa Region. Washington, D.C.: World Bank.

Hérault, N., and J. Thurlow. Forthcoming. Agricultural distortions, poverty, and inequality in South Africa. In Political economy of distortions to agricultural incentives, ed. K. Anderson. Washington, D.C.: World Bank.

Hussmanns, R. 2001. Informal sector and informal employment: Elements of a conceptual framework. Paper presented at the Fifth Meeting of the Expert Group on Informal Sector Statistics, September 19-21, New Delhi.

Kingdon, G. G., and J. Knight. 2004. Unemployment in South Africa: The nature of the beast. World Development 32 (3): 391-408.

Lucas, R. E. B., and J. F. Hofmeyr. 2001. The rise in union wage premiums in South Africa. Labour 15 (4): $685-$ 719 .

Maloney, W. F. 2004. Informality revisited. World Development 32 (7): 1159-1178.

Pauw, K., and L. Edwards. 2006. Evaluating the general equilibrium effects of a wage subsidy for South Africa. South African Journal of Economics 74 (3): 442-462.

Ranchhod, V. 2006. Household responses to adverse income shocks: Pensioner out-migration and mortality in South Africa. Paper presented at the Economic Research Southern Africa's Labor Markets Workshop, September 18-19, Cape Town, South Africa.

Rodrik, D. 2008. Understanding South Africa's economic puzzles. Economics of Transition 16 (4): 769-797.

Schneider, F. 2002. Size and measurement of the informal economy in 110 countries around the world. Paper presented at a workshop at the Australian National Tax Centre, July 17, Canberra, Australia.

Schultz, T. P., and G. Mwabu. 1998. Labor unions and the distribution of wages and employment in South Africa. Industrial and Labor Relations Review 41 (4): 680-703.

StatsSA. 2004. Labor Force Survey September 2004, Statistics South Africa, Pretoria.

StatsSA. 2000. Income and Expenditure Survey 2000, Statistics South Africa, Pretoria.

Thurlow, J. 2002. Can South Africa afford to become Africa's first welfare state? Trade and Macroeconomics Discussion Paper 101. Washington, D.C.: International Food Policy Research Institute. 
Thurlow, J. 2005. A dynamic computable general equilibrium (CGE) model for South Africa: Extending the static IFPRI model. Pretoria, South Africa: Trade and Industrial Policy Strategies.

Thurlow, J. 2007. Trade liberalization and pro-poor growth in South Africa. Journal for Studies in Economics and Econometrics 3 (2): 161-179. 




\section{RECENT IFPRI DISCUSSION PAPERS}

For earlier discussion papers, please go to http://www.ifpri.org/category/publication-type/discussion-papers. All discussion papers can be downloaded free of charge.

942. Recent food prices movements: A time series analysis. Bryce Cooke and Miguel Robles, 2009.

941. Decentralization, agricultural services and determinants of input use in Nigeria. Kamiljon T. Akramov, 2009.

940. How important are peer effects in group lending? Estimating a static game of incomplete information. Shanjun Li, Yanyan Liu, and Klaus Deininger, 2009.

939. Rice production responses in Cambodia. Bingxin Yu and Shenggen Fan, 2009.

938. A latent class approach to investigating consumer demand for genetically modified staple food in a developing country: The case of gm bananas in Uganda. Enoch Kikulwe, Ekin Birol, Justus Wesseler, and José Falck-Zepeda, 2009.

937. Cluster-based industrialization in China: Financing and performance. Cheryl Long and Xiaobo Zhang, 2009.

936. Sensitivity of welfare effects estimated by equilibrium displacement model: A biological productivity growth for semisubsistence crops in Sub-Sahara African market with high transaction costs. Hiroyuki Takeshima, 2009.

935. Assessing household vulnerability to climate change: The case of farmers in the Nile Basin of Ethiopia. Temesgen T. Deressa, Rashid M. Hassan, and Claudia Ringler, 2009.

934. Do external grants to district governments discourage own-revenue generation?: A look at local public finance dynamics in Ghana. Tewodaj Mogues, Samuel Benin, and Godsway Cudjoe, 2009.

933. Impacts of prenatal and environmental factors on child growth: Evidence from Indonesia. Futoshi Yamauchi, Katsuhiko Higuchi, and Rita Nur Suhaeti, 2009.

932. Rich consumers and poor producers: Quality and rent distribution in global value chains. Johan F.M. Swinnen and Anneleen Vandeplas, 2009.

931. Economic growth and distribution of income: A Growth model to fit Ghanaian data. Harumi T. Nelson, Terry L. Roe, and Xinshen Diao, 2009.

930. Trade liberalization, poverty, and food security in India. Manoj Panda and A. Ganesh-Kumar, 2009.

929. Improving the proof: Evolution of and emerging trends in impact assessment methods and approaches in agricultural development. Mywish K. Maredia, 2009.

928. Improving diet quality and micronutrient nutrition: Homestead food production in Bangladesh. Lora Iannotti, Kenda Cunningham, and Marie Ruel, 2009.

927. Land-tenure policy reforms: Decollectivization and the Doi Moi System in Vietnam. Michael Kirk and Tuan Nguyen, 2009.

926. "Crossing the river while feeling the rocks:" Incremental land reform and its impact on rural welfare in China. John W. Bruce and Zongmin Li, 2009.

925. Rich food for poor people: Genetically improved tilapia in the Philippines. Sivan Yosef, 2009.

924 .Rural and urban linkages: Operation Flood's role in India's dairy development. Kenda Cunningham, 2009.

923. The global effort to eradicate rinderpest. Peter Roeder and Karl Rich, 2009.

922. The mungbean transformation: Diversifying crops, defeating malnutrition. Subramanyan Shanmugasundaram, J. D. H. Keatinge, and Jacqueline d'Arros Hughes, 2009.

921. Private sector responses to public investments and policy reforms: The case of fertilizer and maize market development in Kenya. Joshua Ariga and T. S. Jayne, 2009.

920. Institutional reform in the Burkinabè cotton sector and its impacts on incomes and food security: 1996-2006. Jonathan Kaminski, Derek Headey, and Tanguy Bernard, 2009.

919. Pearl millet and sorghum improvement in India. Carl E. Pray and Latha Nagarajan, 2009.910. Combating stem and leaf rust of wheat: Historical perspective, impacts, and lessons learned. H. J. Dubin and John P. Brennan, 2009.

918. Hybrid rice technology development: Ensuring China's food security. Jiming Li, Yeyun Xin, and Longping Yuan, 2009.

917. The impact of shallow tubewells and boro rice on food security in Bangladesh. Mahabub Hossain, 2009. 
INTERNATIONAL FOOD POLICY

RESEARCH INSTITUTE

www.ifpri.org

IFPRI HEADQUARTERS

2033 K Street, NW

Washington, DC 20006-1002 USA

Tel.: +1-202-862-5600

Fax: +1-202-467-4439

Email: ifpri@cgiar.org

IFPRI ADDIS ABABA

P. O. Box 5689

Addis Ababa, Ethiopia

Tel.: +251116463215

Fax: +251116462927

Email: ifpri-addisababa@cgiar.org

IFPRI NEW DELHI

CG Block, NASC Complex, PUSA

New Delhi 110-012 India

Tel.: 9111 2584-6565

Fax: 9111 2584-8008 / 2584-6572

Email: ifpri-newdelhi@cgiar.org 